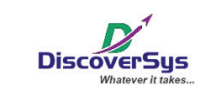

Published by DiscoverSys

\section{Continuation rates for injectable contraception and intra-uterine device (IUD) at Banyuning Village, Buleleng District}

\author{
Lina Anggaraeni Dwijayanti, ${ }^{1,2^{*}}$ Dewa Nyoman Wirawan, ${ }^{2,3}$ Anak Agung Sagung Sawitri ${ }^{2,3}$
}

\section{ABSTRACT}

Background and purpose: Surveys on the proportion of contraception uptake have been regularly conducted in Indonesia, including Bali Province. However, very limited studies have explored contraceptive continuation rates. This study aims to examine continuation rates for injectable contraception and IUD including its determinants.

Methods: A cross-sectional survey was conducted in Buleleng District. A total of 100 reproductive age women who ever used or currently using injectable contraception or IUD were recruited to participate in the study. One village at Buleleng District was purposively selected and samples were selected from all registered reproductive age couples at the village using a systematic random sampling method. Data were collected through home interviews and were analysed using survival analysis to calculate contraceptive continuation rates. Multivariate analysis were performed using cox regression to identify factors associated to continuation rates for injectable contraception and IUD. Analysis was done using STATA SE 12.1.
Results: The one year continuation rate for IUD for first child was $84.62 \%$ whereas for injectable contraception was $71.03 \%$. When sex variable of the child was applied, the one year continuation rate for IUD for first child was higher among those who have male child $(81.82 \%)$ than female child (66.67\%). Similarly, the one year continuation rate for injectable contraception was higher among those who have male child (79.10\%) than female child (57.58\%). The one year contraceptive continuation rate is also higher for the second child than the first one (79.56 vs 71.03 for injectable and 87.88 vs 84.62 for IUD). The multivariate analysis showed that perceived quality of family planning services was associated to contraceptive continuation rates (AHR=2.54; 95\%Cl: 1.22-5.29).

Conclusions: The continuation rate for IUD was higher than injectable contraception. Higher contraceptive continuation rate was found among those who have male children. The contraceptive continuation rate was associated with perceived quality of family planning services. Interventions to improve the quality of family planning services are warranted.

Keywords: continuation rates, injectable contraception, IUD, Buleleng, Bali

Cite This Article: Dwijayanti, L.A., Wirawan, D.N., Sawitri, A.A.S. 2017. Continuation rates for injectable contraception and intra-uterine device (IUD) at Banyuning Village, Buleleng District. Public Health and Preventive Medicine Archive 5(2): 79-83. D0I:10.15562/phpma.v5i2.18

${ }^{1}$ Buleleng Health Institute,

2Public Health Postgraduate Program Udayana University, ${ }^{3}$ Department of Community and Preventive Medicine Faculty of Medicine Udayana University

*Correspondence to: Lina Anggaraeni Dwijayanti, Buleleng Health Institute anggaraenilina@yahoo.com

\section{INTRODUCTION}

Fertility rate is determined by eight determinants, including contraceptive use. ${ }^{1}$ Over the last 10 years, fertility rate in Indonesia is steady at 2.6 children per woman. In contrast, fertility rate in Bali Province was increased from 2.1 in 2002 to 2.3 in $2012 .^{2,3}$ The overall proportion of contraceptive use in Indonesia was increased from $57.4 \%$ in 2007 to $57.9 \%$ in 2012; the opposite trend was observed for Bali Province where the proportion of contraceptive use among married women was decreased from $65.4 \%$ in 2007 to $59.6 \%$ in $2012 .{ }^{2,3}$ The 2013 National Health Survey (Riskesdas) found that the overall proportion of contraceptive use in Indonesia was increased from $55.8 \%$ in 2010 to $59.7 \%$ in 2013 , while in Bali Province was steady at $60 \%$ between 2010 and 2013. ${ }^{4}$ Surveys on contraception use have been regularly conducted in Indonesia, ${ }^{2-4}$ however survey on contraceptive continuation rates is rarely been done. Several studies have revealed that contraceptive continuation rates are associated with age, parity, ${ }^{5}$ education level, employment, ${ }^{6}$ and socio-economic status. ${ }^{7}$ In addition, the quality of health services and support from husband are also associated with contraceptive continuation rates. ${ }^{8}$ This study aims to examine contraceptive continuation rates and its determinants in Buleleng District, Bali Province.

\section{METHODS}

Banyuning Village was purposively selected because it is the largest village in Buleleng District with the highest number of reproductive age couples. The social-economic variables of Banyuning Village were comparable to the rest of the villages in Buleleng District as can be seen from the proportion of poor households. In 2006, the proportion of poor households in Banyuning Village was 14.30\%, only slightly lower than the average proportion of Buleleng District of $18.85 \%$ and Bali Province of $17.9 \%$. 
A cross-sectional survey was conducted at Banyuning Village. Data were retrospectively obtained. Out of 2013 reproductive age couples, 100 women who ever used or currently using IUD or injectable contraception were selected using a systematic random sampling.

Data collected included age, parity, sex of the children, education, employment status, family income, perceived quality of health services, support from husband, healthcare facilities, and contraceptive continuation rates. Data were collected from March to April 2017 through home interviews. Data were analysed using STATA SE 12.1. A survival analysis was employed to determine contraceptive continuation rates. Cox regression was used to examine factors associated to contraceptive continuation rates. The last contraception method was used for the multivariate analysis. This study protocol has been approved by the Human Research Ethic Committees Faculty of Medicine Udayana University and Sanglah General Hospital Denpasar.

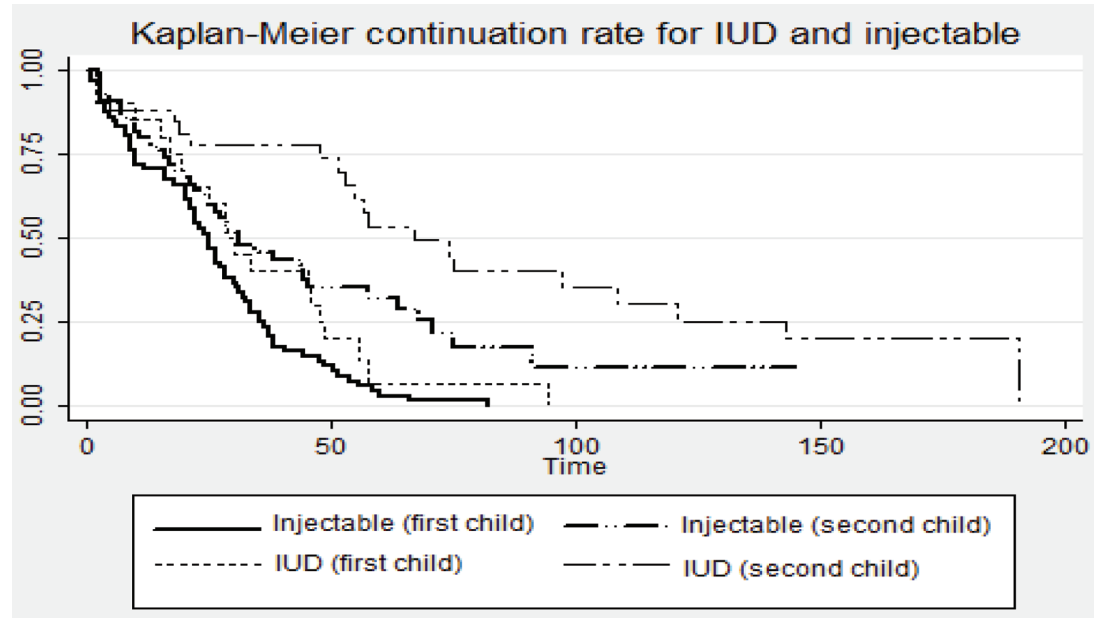

Figure 1 Kaplan-Meier for continuation rates for IUD and injectable contraception among the first and second child

Table 1 Continuation rates for IUD and injectable contraception among the first and second child

\begin{tabular}{lccccc}
\hline & \multicolumn{2}{c}{ Injectable contraceptive } & & \multicolumn{2}{c}{ IUD } \\
\cline { 2 - 3 } \cline { 5 - 6 } Month & First child & Second child & & First child & Second child \\
\hline 12 & 71.03 & 79.56 & & 84.62 & 87.88 \\
18 & 66.91 & 71.65 & & 73.91 & 87.86 \\
24 & 52.75 & 63.69 & & 63.46 & 77.73 \\
36 & 25.66 & 45.62 & & 42.31 & 77.73 \\
48 & 14.26 & 34.98 & & 26.44 & 74.39 \\
60 & 4.28 & 32.07 & & 8.81 & 54.29 \\
72 & 1.43 & 22.25 & & - & 49.95 \\
84 & 0.00 & 17.80 & & - & 40.43 \\
Median & 25.33 & 30.43 & & 26.40 & 66.97 \\
\hline
\end{tabular}

\section{RESULTS}

The majority of respondents were aged between $14-34$ years $(85 \%)$; with parity of $>2(65 \%)$; have a male child ( $82 \%)$; being employed (72\%); with education level up to junior high school (58\%); and with a family income of $\leq 2,372,000$ rupiah or USD 197 (54\%). The average age for respondents' husband was 37 years; working in informal sector $(53 \%)$ and with education level of senior high school and above (62\%). The majority of respondents were not supported by their husband on contraception use (60\%), had low perceived quality of services (56\%), and accessed private services for contraceptive services (88\%). As many as $63 \%$ of respondents were current user with contraception mix of injectable contraception (60.3\%), IUD (31.7\%) and pill contraception (8.0\%).

Table 1 shows continuation rates for IUD was higher than injectable contraception for both first and second child. Continuation rates for both IUD and injectable contraception were higher among second child than first child. The one year continuation rate for IUD for first child was $84.62 \%$ and $87.88 \%$ for second child, whereas for injectable contraception was $71.03 \%$ for first child and $79.56 \%$ for second child. The five year continuation rate for IUD was $8.81 \%$ for first child and $54.29 \%$ for second child, while for injectable contraception was only $4.28 \%$ and $32.07 \%$ for first and second child respectively.

Figure 1 shows continuation rates for IUD and injectable contraception. It can be observed that the continuation rate for IUD was higher than injectable contraception with prominent difference was observed among the second child and the first one. The continuation rate also differed based on sex of the child. Table 2 demonstrates the one year continuation rate and can be observed that the one year continuation rate for both IUD and injectable contraception was higher among those who have male child than female child. This different was more prominent for the first child.

Table 3 shows bivariate and multivariate analyses using backward method for the last contraception method used by respondents. All variables with $p$-value $>0.25$ were excluded one by one - started from variable with the highest p-value that were in order: parity, sex of the child, family income, place of services, support from husband, and employment status. Multivariate analysis revealed that perceived quality of services contributed the most to continuation rates for the last contraception method used by respondents $(\mathrm{AHR}=2.54 ;$; $95 \% \mathrm{CI}: 1.22-5.29)$. 
Table 2 Contraceptive continuation rates based on sex variable of the child

\begin{tabular}{|c|c|c|c|c|c|c|c|c|}
\hline \multirow[b]{2}{*}{ Month of- } & \multicolumn{2}{|c|}{ Injectable first child } & \multicolumn{2}{|c|}{ IUD first child } & \multicolumn{2}{|c|}{ Injectable second child } & \multicolumn{2}{|c|}{ IUD second child } \\
\hline & Female & Male & Female & Male & Female & Male & Female & Male \\
\hline 12 & 57.58 & 79.10 & 66.67 & 81.82 & 77.78 & 87.23 & 86.21 & 88.57 \\
\hline 24 & 36.36 & 60.49 & 50.00 & 72.73 & 62.72 & 69.79 & 86.21 & 70.86 \\
\hline 36 & 12.12 & 35.02 & 33.33 & 45.45 & 36.59 & 52.34 & 86.21 & 70.86 \\
\hline 48 & 6.06 & 19.10 & 11.11 & 27.27 & 20.91 & 47.79 & 76.06 & 64.11 \\
\hline 60 & 0.00 & 9.55 & - & 0.09 & 14.93 & 47.79 & 32.60 & 56.57 \\
\hline 72 & - & 3.18 & - & 0.00 & 14.93 & 31.86 & 21.73 & 47.86 \\
\hline 84 & - & 0.00 & - & - & 0.00 & 31.86 & 10.87 & 38.29 \\
\hline
\end{tabular}

Table 3 Incidence and predictors of discontinuation for the last contraception method

\begin{tabular}{|c|c|c|c|c|c|c|c|}
\hline \multirow[b]{2}{*}{ Variables } & \multicolumn{4}{|c|}{ Bivariate } & \multirow[b]{2}{*}{$\begin{array}{c}\mathbf{p} \\
\text { value }\end{array}$} & \multicolumn{2}{|c|}{ Multivariate } \\
\hline & $\mathbf{n}$ & $\begin{array}{c}\text { Observation } \\
\text { (month) }\end{array}$ & $\begin{array}{c}\text { Incidence (per } 100 \\
\text { person months) }\end{array}$ & $\begin{array}{c}\text { Crude hazard } \\
\text { ratio }\end{array}$ & & $\begin{array}{c}\text { Adjusted } \\
\text { hazard ratio }\end{array}$ & $95 \% \mathrm{Cl}$ \\
\hline \multicolumn{8}{|l|}{ Age } \\
\hline 14-34 years & 35 & 3509 & 0.99 & & & & \\
\hline$\geq 35$ years & 2 & 594 & 0.34 & 0.34 & 0.14 & 0.33 & $0.08-1.36$ \\
\hline \multicolumn{8}{|l|}{ Child sex } \\
\hline Male (present) & 30 & 3567 & 0.84 & & & & \\
\hline Male (absent) & 7 & 536 & 1.31 & 1.43 & 0.40 & & \\
\hline \multicolumn{8}{|l|}{ Parity } \\
\hline$>2$ & 11 & 1294 & 0.85 & & & & \\
\hline$\leq 2$ & 26 & 2809 & 0.93 & 1.06 & 0.87 & & \\
\hline \multicolumn{8}{|l|}{ Employment Status } \\
\hline Employed & 26 & 3336 & 0.77 & & & & \\
\hline Unemployed & 11 & 767 & 1.40 & 1.64 & 0.18 & & \\
\hline \multicolumn{8}{|l|}{ Education } \\
\hline$\geq$ Senior high & 14 & 1332 & 1.10 & & & & \\
\hline$\leq$ Junior high & 23 & 2770 & 0.83 & 0.89 & 0.73 & 0.60 & $0.29-1.24$ \\
\hline \multicolumn{8}{|l|}{ Family income } \\
\hline$>2,372,000$ IDR & 15 & 1877 & 0.79 & & & & \\
\hline$\leq 2,372,000 \mathrm{IDR}$ & 22 & 2226 & 0.98 & 1.24 & 0.55 & & \\
\hline \multicolumn{8}{|c|}{ Support from husband } \\
\hline Adequate & 12 & 1748 & 0.68 & & & & \\
\hline Inadequate & 25 & 2355 & 1.06 & 1.58 & 0.20 & & \\
\hline \multicolumn{8}{|c|}{ Perceived quality of services } \\
\hline Adequate & 13 & 2234 & 0.58 & & & & \\
\hline Inadequate & 24 & 1869 & 1.28 & 2.22 & 0.02 & 2.54 & $1.22-5.29$ \\
\hline \multicolumn{8}{|l|}{ Service provider } \\
\hline Private & 4 & 655 & 0.61 & & & & \\
\hline Public & 33 & 3448 & 0.96 & 0.70 & 0.51 & & \\
\hline
\end{tabular}

\section{DISCUSSION}

Our study found that the current user was $63.0 \%$, with contraception mix of injectable method (60.3\%), IUD (31.7\%), and pill contraception (8.0\%).
Our finding is higher when compared to data from the 2012 Indonesia Demographic and Health Survey for Bali Province, which found current user of 
contraceptive use 59.6\%, with contraception mix of injectable method (21.6\%), IUD (19.0\%), pill contraception (21.6\%), and other methods including tubectomy, vasectomy, implant and condom (9.9\%). ${ }^{3}$ Our study confirmed that the proportion of IUD use is relatively stable, while our study also found that the proportion of injectable method is relatively higher and pill contraception is relatively lower.

In this present study, continuation rates for pill contraceptive was not assessed due to small sample size. The one year continuation rate for IUD was $84.62 \%$ for first child and $87.88 \%$ for second child. This finding is similar with a study conducted in Bali Province in 1982, which was $83.9 \% .^{9}$ The continuation rate for injectable method was $71.03 \%$ for first child and $79.56 \%$ for second child. A study in 1982 found only $51.9 \% .{ }^{9}$ Our study confirmed that continuation rates for IUD were higher than injectable method which is consistent with the majority of studies being done in Indonesia or other countries. The 2007 Indonesia Demographic and Health Survey showed that the continuation rate for IUD was $90.1 \%$ while for injectable method was only $77 \% .^{2}$ In addition, the 2002-2006 Demographic and Health Survey (DHS) revealed that the continuation rate for IUD in several countries was varied between $64.5 \%$ and $93.9 \%$ while for injectable method was only between $32.2 \%$ and $81.9 \% .^{10}$

In our study, contraceptive continuation rates among second child were higher than the first child. This finding is probably associated with the desire of respondents to have two children. Similar finding was also reported in the 2007 National Basic Health Survey, which found that contraceptive continuation rates among women with higher parity were higher than those with low parity. ${ }^{11}$ A study conducted in Alexandria also found that women with three or four children have higher contraceptive continuation rates than those who have one child or two children. ${ }^{12}$

Our study found that contraceptive continuation rates differed based on sex variable of the children where higher continuation rates were associated with male child. In the bivariate analysis, we categorized our respondents as those with male child and those without male child. We found that the discontinuation rate among those who do not have male child was 1.31 per 100 person month while those who have male child was only 0.84 per 100 person month (CHR=1.43; 95\%CI: 0.62-3.33). Though this trend is not statistically significant, this might be related to the Balinese culture that promotes patriarchal and patrilineal systems where male children are perceived as the backbone of families and hold the family ancestry line. ${ }^{13}$ Similar finding is also found in provinces of Hebei and Shandong, China that also adopt patriarchal culture. Study in these provinces revealed that contraceptive continuation rates among women who have male child were higher than those who have female child. ${ }^{14}$

Multivariate analysis of our study showed that the only factor contributed to the last contraceptive continuation rate is the perceived quality of services $(\mathrm{AHR}=2.54$; 95\%CI: 1.22-5.29). Sex variable of the child and parity were not statistically associated with the last contraceptive discontinuation rate. Our study adopted a framework developed by Bruce when assessing the quality of family planning services, which included six elements of services: choice of methods, information given to clients, technical competence, interpersonal relations, follow-up and continuity mechanisms, and the appropriate constellation of services. ${ }^{15}$ Several studies in Indonesia and other countries also showed that contraceptive continuation rate is associated with quality of services. ${ }^{16-18}$ In order to increase contraceptive continuation rates, family planning services need to be improved based on the above six elements.

Limitation of our study is that it involves only one village therefore finding from this study cannot be extrapolated to a wider population. However, the characteristics of our study site are quite similar with the rest of villages in Bali Province. Other limitation of our study is that data were retrospectively collected leading to probable recall bias, especially when related to the start and end date of the contraceptive use.

\section{CONCLUSION}

Continuation rate for IUD was higher than injectable. Contraceptive continuation rate was higher for the second child than the first one. Contraceptive continuation rates were also higher among those who have male child than those who have only female child. The contraceptive continuation rate was significantly associated with perceived quality of health services. In order to improve contraceptive continuation rates, improvement on the quality of family planning services is warranted.

\section{ACKNOWLEDGEMENT}

Researcher would like to thank the head of village, family planning workers, health cadres, and all respondents who have supported this study.

\section{REFERENCES}

1. Bongaarts. A framework for analyzing the proximate determinants of fertility. in: William Brass, L.Jolly C, editors. Population dynamics of Kenya [Internet]. Washington, DC: The National Academies Press; 1993.

2. Statistics Indonesia, National Family Planning Coordinating Board, Ministry of Health, Macro International. Indonesia Demographic and Health Survey 2007. Jakarta: Statistics Indonesia, National Family Planning Coordinating Board, Ministry of Health, Macro International; 2008. 
3. Ministry of Health of Indonesia. Statistics Indonesia, national population and family planning board, ministry of health, measure DHS ICF International. Indonesia Demographic and Health Survey 2012. Jakarta: Ministry of Health of Indonesia; 2013.

4. Ministry of Health of Indonesia. Riset kesehatan dasar 2013 [The 2013 Basic Health Survey]. Jakarta: Ministry of Health of Indonesia; 2013.

5. Khader Yousef S, El-Qaderi Saleh KAM. Intrauterine contraceptive device discontinuation among jordanian women: rate, causes and determinants. Journal Family Planning Reproductive Health Care. 2006; 32(3): 161-164.

6. Sariana S. Kelangsungan penggunaan kontrasepsi di Indonesia [Continuation rates of contraception in Indonesia]. Jurnal Kesehatan Masyarakat Nasional. 2009; 3(5): 206-11.

7. James T, Vaughan Barbara. Contraceptive failure, method related discontinuation and resumption of use: results from the 1995 national survey of family growth. Family Planning Perspective. 1999; 31(2):64-93.

8. Bayu RM. Kualitas pelayanan keluarga berencana dan penggantian kontrasepsi di indonesia [Quality of service of family planning and contraceptive substitution in Indonesia]. Jurnal Kesehatan Masyarakat Nasional. 2011;6(3):140-4.

9. Wirawan D. Penelitian pengembangan dengan sistem moduler, suatu penelitian tentang ciri-ciri sosial ekonomi, keluarga berencana, fertilitas, kesehatan dan kelangsungan pemakaian alat kontrasepsi di Bali [A development research with moduler system, a study on socio-economic, family planning, fertility, health and continuation rates of contraception in Bali province]. Denpasar: Faculty of Medicine, Udayana University/Bali Family Planning Coordination Board; 1984.

10. Bradley, Sarah E.K., Hilary M. Schwandt and SK. Levels, trends, and reasons for contraceptive discontinuation. DHS analytical studies No. 20. Calverton, Maryland, USA; 2009.
11. National Family Planning Coordination Board. Analisa lanjut data SDKI tahun 2007: kelangsungan pemakaian kontrasepsi [Advanced analysis of the 2007 Indonesian Demographic and Health Survey: contraceptive continuation rates]. Jakarta: National Family Planning Coordination Board; 2009

12. Mahdy NH, N.A.El-Zeiny. Probability of contraceptive continuation and its determinants. Eastern Mediterranean Health Journal. 1999; 5(3): 526-39.

13. Tirsani NMAD. Value children pada keluarga bali ditinjau dari jenis kelamin anak [The value of children based on sex in Bali society] [thesis]. Surabaya: University of Surabaya; 2013.

14. Ping T. IUD Discontinuation patterns and correlates in four counties in North China. Studies in Family Planning. 1995; 26(3): 169-79.

15. Bruce J. Fundamental elements of the quality of care: a simple framework. Studies in Family Planning. 1990; 21: 61-91.

16. Priyono YE. Hubungan kualitas pelayanan keluarga berencana dengan kelangsungan pemakaian alat kontrasepsi dalam rahim (akdr) di Kabupaten Purworejo [Association between quality of family planning service and continuation rates of intra-uterine devices contraception] [thesis]. Yogyakarta: Gadjah Mada University; 2000.

17. Hubacher D, Goco N, Gonzalez B, Taylor D. Factors affecting continuation rates of DMPA. Contraception. 1999; 60(6): 345-51.

18. Aldrie, Henry-Lee. Women's reasons for discontinuing contraceptive use within 12 months: Jamaica. Reproductive Health Matters. 2001; 9(17): 213-20.

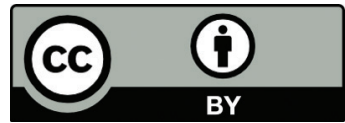

This work is licensed under a Creative Commons Attribution 